\title{
Pemberdayaan Guru Raudhatul Athfal (RA) Melalui Edukasi Media Visual "Buku Bantal Bilingual” di Sukosono Kedung Jepara Jawa Tengah
}

\author{
${ }^{1)}$ Santi Andriyani, ${ }^{1)}$ Yushinta Eka Farida, ${ }^{2)}$ DS. Drajat Wibowo \\ ${ }^{1}$ Fakultas Tarbiyah dan Ilmu Keguruan UNISNU Jepara \\ santiandriyani6@gmail.com; faridayushinta@gmail.com.. \\ ${ }^{3}$ Fakultas Sains dan Teknologi UNISNU Jepara \\ dragong917@gmail.com
}

\begin{abstract}
Media has an important role in the learning process of early childhood. Media can be used as a tool to facilitate learning process to be effective and eficient. This program is done at Raudhatul Athfal (RA) AlMasithoh and Raudhatul Athfal Miftahul Ulum, both are located in Sukosono, Kedung, Jepara. The objectives of this program are: (1) to develop the creativity of $R A$ teachers on creating instructional media; (2) to increase the knowledge and skills of $\mathrm{R} A$ teachers on learning media, called softbook; (3) to improve the linguistic intelligence of students using bilingual softbook as a learning medium. The methods used are education, training, education, and practice. The results of this program are: (1) the output or product in this program is a softbook (buku bantal) made from spons ati as the basic material. It is related to $\mathrm{R} A$ theme with bilingual concept (Indonesian and English) and (2) schools could practice of making the bilingual softbook according to the stages started from drawing, painting, writing, sticking, decorating, sewing, and the last is finishing.
\end{abstract}

Keywords: Softbook, Visual Media, Early Childhood, Buku Bantal Bilingual.

\section{Pendahuluan}

Pendidikan usia dini merupakan wahana pendidikan yang sangat fundamental untuk berkembangnya dasar-dasar pengetahuan, sikap/perilaku dan keterampilan pada anak. Keberhasilan proses pendidikan pada masa tersebut menjadi dasar untuk proses pendidikan selanjutnya. Keberhasilan penyelenggaraan pendidikan pada lembaga pendidikan anak dini, seperti: kelompok bermain, Taman Penitipan Anak (TPA) maupun Taman KanakKanak/Raudlatul Athfal sangat bergantung pada sistem dan proses pendidikan yang dijalankan.

Dalam melaksanakan proses belajar mengajar untuk anak usia dini, guru hendaknya memiliki pemahaman yang baik tentang materi yang akan diberikan kepada anak dan menyiapkan alat peraga apa yang akan digunakan untuk pembelajaran di kelas. Alat peraga ini adalah salah satu sumber belajar yang sangat diperlukan untuk mengembangkan aspek-aspek perkembangan anak usia dini termasuk TK/RA.

Sujiono \& Sujiono dalam Yuliani Nurani Sujiono menyatakan bahwa aktifitas proses belajar mengajar pada anak usia dini pada hakikatnya merupakan pengembangan kurikulum

Volume 2, Number 1, Mei 2018| 120 Pemberdayaan Guru RA Melalui Edukasi Media Visual “Buku Bantal Bilingual” di Sukosono Kedung Jepara Jawa Tengah Santi Andriyani, Yushinta Eka Farida, DS. Drajat Wibowo 


\section{ENGAGEMENT}

Gurnal Pengabdian Kepada Masyarakat

ISSN: 2579-8375 (Print)

ISSN: 2579-8391 (Online)

secara konkret yang berupa seperangkat perencanaan berisi sejumlah pengalaman belajar anak usia dini yang dilaksanakan melalui bermain berdasarkan potensi dan tugas perkembangan yang harus dimilikinya untuk pencapaian kompetensi anak ${ }^{1}$.

Novan Ardy Wiyani \& Barnawi menyatakan bahwa pembelajaran yang berorientasi pada anak usia dini yang disesuaikan dengan tingkat usia anak, artinya pembelajaran harus diminati, kemampuan yang diharapkan dapat dicapai, serta kegiatan belajar dapat menantang peserta didik untuk dilakukan sesuai usia anak².

Suyadi juga berpendapat, bahwa standar kompetensi anak usia dini terdiri atas beberapa aspek yaitu, pengembangan aspek-aspek moral dan nilai-nilai agama, sosial emosional dan kemandirian, bahasa, kognitif, fisik-motorik, dan seni ${ }^{3}$. Catron dan Allen dalam Yuliani Nurani Sujiono, menyatakan bahwa terdapat 6 aspek perkembangan anak usia dini, yaitu kesadaran personal, kesehatan emosional, sosialisasi, komunikasi, kognisi, dan keterampilan motorik ${ }^{4}$.

Dari berbagai deskripsi diatas, dapat disimpulkan bahwa supaya semua perkembangan dan pertumbuhan anak usia dini dapat tercapat maksimal, maka perlu pembelajaran yang tepat, yang sesuai dengan usia mereka, dan bersifat menyenangkan. Maka dari itu, perlu adanya media pembelajaran yang menarik dan menyenangkan untuk dapat memfasilitasi pembelajaran anak usia dini.

Khadijah menyatakan bahwa media pembelajaran merupakan segala sesuatu yang dapat dimanfaatkan untuk menyalurkan pesan. Pesan tersebut dikirim oleh pengirim pesan kepada penerima pesan sehingga hal tersebut dapat merangsang pikiran, perasaan, perhatian dan minat serta perhatian anak usia dini. ${ }^{5}$

Kemp \& Dayton dalam buku Azhar mengemukakan beberapa hasil penelitian yang menunjukan dampak positif dari penggunaan media pembelajaran yaitu ${ }^{6}:$ (1) membuat pembelajaran menjadi lebih baku ; (2) pembelajaran dapat lebih menarik; (3) pembelajaran lebih interaktif; dan (4) waktu pelaksanaan pembelajaran akan lebih efisien.

\footnotetext{
Yuliani Nurani Sujiono,Konsep Dasar Pendidikan Anak Usia Dini. Jakarta: PT. Indeks. 2011), 138.

${ }^{2}$ Novan Ardy Wiyani \& Barnawi, Format PAUD (Jakarta: Arr-Ruzzmedia, 2012), 88.

${ }^{3}$ Suyadi, Psikologi Belajar Anak Usia Dini( Yogyakarta: PEDAGOGIA, 2010), 10.

${ }^{4}$ Yuliani Nurani Sujiono ,Opcit, 62

${ }^{5}$ Khadijah, Media Pembelajaran AUD (Medan: Perdana Publishin, 2016), 124.

${ }^{6}$ Azhar Arsyad, Media Pembelajaran (Jakarta: Raja Grafindo Persada, 2014), 25.
} 


\section{ENGAGEMENT}

Gurnal Pengabdian Kepada Masyarakat

ISSN: 2579-8375 (Print)

ISSN: 2579-8391 (Online)
This work is licensed under a Creative Commons Attribution-ShareAlike 4.0 International License.

Secara umum manfaat media pembelajaran menurut Hamalik $^{7}$ adalah memperlancar interaksi antara guru dengan anak sehingga kegiatan pembelajaran lebih afektif dan efisien. Sedangkan secara khusus manfaat media pembelajaran adalah: (1) dalam penyampaian materi pembelajaran dapat diseragamkan; (2) proses pembelajaran menjadi lebih jelas dan menarik; (3) Proses pembelajaran menjadi lebih interaktif karena dengan media akan terjadinya komukasi dua arah secara aktif, sedangkan tanpa media guru cenderung bicara satu arah; (4) dengan media tujuan belajar akan lebih mudah tercapai secara maksimal dengan waktu dan tenaga seminimal mungkin; (5) meningkatkan kualitas hasil belajar anak; (6) media memungkinkan proses belajar dapat dilakukan di mana saja dan kapan saja; (7) media dapat menumbuhkan sikap positif anak terhadap materi dan proses belajar, dan (8) mengubah peran guru ke arah yang lebih positif dan produktif.

\section{Kondisi Dampingan}

Lokasi kedua komunitas dampingan pada pengabdian ini terletak di Desa Suksono yang terletak sebelah selatan kota Jepara. Berdasarkan data monografi, desa Sukosono memiliki luas \pm 383.352 Ha. Secara geografis Sukosono terletak 8 meter dari permukaan air laut, beriklim tropis dengan curah hujan $6,70 \mathrm{~mm} /$ th, temperatur suhu udara rata-rata $33^{\circ} \mathrm{C}$.

Sedangkan secara topografis, kondisi wilayahnya terdiri atas 73,62\% tanah pekarangan, tegalan yang kering dan 26,38 \% berupa tanah sawah tadah hujan. Desa Sukosono merupakan desa paling ujung utara Kecamatan Kedung, yang berbatasan sebelah: selatan Desa Kerso, Dongos, sebelah barat Desa Rau, Petekeyan, sebelah utara Desa Sukodono dan Langon, sebelah timur Desa Ngabul.

Lembaga pendidikan yang ada di desa Sukosono terbilang cukup banyak, sebagaimana tersaji dalam table 1 berikut ini.

Tabel 1. Lembaga Pendidikan di Sukosono

\begin{tabular}{llll}
\hline No & $\begin{array}{l}\text { Bentuk } \\
\text { Pendidikan }\end{array}$ & \multicolumn{2}{c}{ Nama Lembaga Pendidikan } \\
\hline \multirow{2}{1}{$\mathbf{1}$} & Formal & RA Miftahul Ulum & SD Sukosono 3 \\
\cline { 3 - 4 } & & RA Al-Masithoh & SD Sukosono 4 \\
\cline { 3 - 4 } & & RA Al-Fatmiyyah & SD Sukosono 5 \\
\cline { 3 - 3 } & & TK Satu Atap Pertiwi & MTs Miftahul Ulum \\
\cline { 3 - 4 } & & MI Miftahul Ulum & MA Miftahul Ulum \\
\cline { 3 - 4 } & & MI Sultan Fattah & MTs Sultan Fattah \\
\hline
\end{tabular}

${ }^{7}$ Hamalik, Keterampilan Dasar Mengajar (Malang: Fakultas Tarbiyah Press, 2005), 26.

Volume 2, Number 1, Mei 2018| 122 Pemberdayaan Guru RA Melalui Edukasi Media Visual “Buku Bantal Bilingual” di Sukosono Kedung Jepara Jawa Tengah Santi Andriyani, Yushinta Eka Farida, DS. Drajat Wibowo 


\begin{tabular}{lll}
\hline \multirow{2}{*}{ Non Formal } & SD Sukosono 1 & MA Sultan Fattah \\
\cline { 2 - 3 } & SD Sukosoni 2 & SMPN 3 Satu Atap \\
\cline { 2 - 3 } & PAUD Al-Masithoh & TPQ Hidayatul Mubtadiin \\
\cline { 2 - 3 } & Madin Hidayatul Mubtadiin & TPQ Ismailiyah \\
\cline { 2 - 3 } Madin Miftahul Ulum & TPQ Ari-Ari \\
\cline { 2 - 3 } Madin Ismailiyah & TPQ Assalamah \\
\cline { 2 - 2 } & Madin Assalamah & PKBM Al-Wathoniyah \\
\cline { 2 - 2 } & Ponpes Al-Wasath & Ponpes Hidayatussalam \\
\cline { 2 - 2 } & Pondok thoriqoh Al-Muhtadin & TBM Sultan Fattah \\
\cline { 2 - 2 } & Ponpes Mambaul Qur'an & Ponpes Al-Wathoniyah \\
\cline { 2 - 2 } & Ponpes Assalamah & \\
\hline
\end{tabular}

Komunitas dampingan pada program pengabdian ini adalah dua lembaga pendidikan tingkat Raudhatul Athfal (RA) atau sejenis dengan Taman Kanak-kanak (TK) yang terletak di desa Sukosono, kecamatan Kedung, kabupaten Jepara, Jawa Tengah. Kedua komunitas dampingan tersebut adalah RA Al-Masithoh dan RA Miftahul Ulum.

Sesuai dengan sasaran komunitas dampingan yaitu anak usia dini, maka tujuan secara khusus dari kedua lembaga tersebut adalah untuk memantapkan perkembangan emosi, fisik, dan sosial untuk siap mengikuti pendidikan selanjutnya.

Berikut situasi kedua komunitas dampingan:

\section{Komunitas dampingan Dampingan 1 : RA Al-Masithoh Sukosono}

Tabel 2. Profil RA Al-Masithoh

\begin{tabular}{|c|c|c|}
\hline 1 & Nama TK/RA & Al MASITHOH \\
\hline 2 & Status & RA Swasta \\
\hline 3 & Alamat TK/RA & $\begin{array}{l}\text { Jln. Sultan Fattah RT } 09 \text { RW } 03 \text { Sukosono Kedung } \\
\text { Jepara }\end{array}$ \\
\hline 4 & Nama Kepala Sekolah & Hanna Sofiana, S.Pd.I \\
\hline 5 & Nama Yayasan & Sultan Fattah \\
\hline 6 & Alamat Yayasan & $\begin{array}{l}\text { Jln. Sultan Fattah RT } 10 \text { RW } 03 \text { Sukosono Kedung } \\
\text { Jepara }\end{array}$ \\
\hline 7 & Jumlah siswa tahun 2016 & 46 siswa terdiri dari $20 \mathrm{TK}$ A dan $26 \mathrm{TK} \mathrm{B}$ \\
\hline 8 & Jumlah Guru & $\begin{array}{l}6 \text { orang dengan perincian pendidikan terakhir: } \\
4 \text { guru : S1; } 2 \text { guru : SMA }\end{array}$ \\
\hline 9 & Fasilitas Sekolah & $\begin{array}{l}\text { Ruang kepala sekolah, ruang kelas, toilet dan dapur, serta } \\
\text { tempat bermain diluar }\end{array}$ \\
\hline 10 & Sarana dan prasarana & $\begin{array}{l}\text { Almari kelas (rusak ringan), meja dan kursi guru meja dan } \\
\text { kursi anak (rusak ringan), listrik, dan rak (rusak ringan). }\end{array}$ \\
\hline 11 & Alat permainan & $\begin{array}{l}\text { Seluncur, ayunan (rusak), jungkitan, komedi putar, bola } \\
\text { dunia }\end{array}$ \\
\hline
\end{tabular}

Volume 2, Number 1, Mei 2018| 123

Pemberdayaan Guru RA Melalui Edukasi Media Visual “Buku Bantal Bilingual” di Sukosono Kedung Jepara Jawa Tengah

Santi Andriyani, Yushinta Eka Farida, DS. Drajat Wibowo 


\section{ENGAGEMENT}

Gurnal Pengabdian Kepada Masyarakat

ISSN: 2579-8375 (Print)

ISSN: 2579-8391 (Online)
This work is licensed under a Creative Commons

Attribution-ShareAlike 4.0 International License.

CC BY SA

\section{Komunitas dampingan Dampingan 2 : RA Miftahul Sukosono}

Tabel 3. Profil RA Miftahul Ulum

\begin{tabular}{|c|c|c|}
\hline 1 & Nama TK/RA & RA. MIFTAHUL ULUM \\
\hline 2 & Status & RA Swasta \\
\hline 3 & Alamat TK/RA & $\begin{array}{l}\text { Jl. Krajan Tugu Ngempet Rt : } 27 \mathrm{Rw}: 07 \text { Sukosono } \\
\text { Kedung Jepara }\end{array}$ \\
\hline 4 & Nama Kepala Sekolah & Siti Zulaikhah, S.Pd.I \\
\hline 5 & Nama Yayasan & Yayasan Pendidikan Islam Miftahul Ulum \\
\hline 6 & Alamat Yayasan & $\begin{array}{l}\text { Jl. Krajan Tugu Ngempet Rt : } 27 \text { Rw : } 07 \text { Sukosono } \\
\text { Kedung Jepara }\end{array}$ \\
\hline 7 & Jumlah siswa tahun $2016 / 2017$ & 53 siswa terdiri dari 24 TK A dan 29 TK B \\
\hline 8 & Jumlah Guru & 6 orang dengan pendidikan terakhir S1 \\
\hline 9 & Fasilitas Sekolah & $\begin{array}{l}\text { Ruang kepala sekolah (rusak ringan), ruang kelas, dan } \\
\text { toilet (rusak ringan) }\end{array}$ \\
\hline 10 & Sarana dan prasarana & $\begin{array}{l}\text { Almari kelas (rusak ringan), meja dan kursi guru meja } \\
\text { dan kursi anak (rusak ringan), listrik, rak (rusak } \\
\text { ringan), tape recorder (rusak ringan) VCD (rusak } \\
\text { ringan) dan TV (rusak ringan). }\end{array}$ \\
\hline 11 & Alat permainan & $\begin{array}{l}\text { Ayunan (rusak berat), jungkitan (rusak ringan), } \\
\text { luncuran (rusak ringan) }\end{array}$ \\
\hline
\end{tabular}

Untuk mencapai tujuan pendidikan diatas, diperlukan beberapa elemen yang harus saling mendukung satu sama lain. Elemen tersebut meliputi guru, kurikulum, metode, media, dan fasilitas sekolah. Oleh karena itu, kedua komunitas dampingan berusaha secara maksimal untuk dapat memenuhi elemen tersebut demi tercapai tujuan yang diharapkan.

Berdasarkan hasil analisis situasi di atas, observasi dan interview dengan Kepala sekolah RA Al- Masithoh dan RA Miftahul Ulum, maka permasalahan yang paling menonjol pada kedua komunitas dampingan adalah tidak adanya media pembelajaran yang menarik dalam proses belajar mengajar anak.

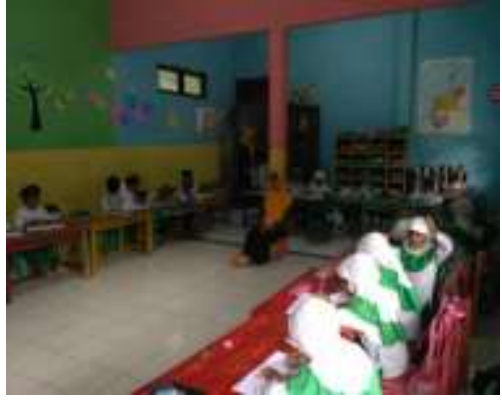

Gambar 1. Model pembelajaran yang ada di RA Al Masithoh

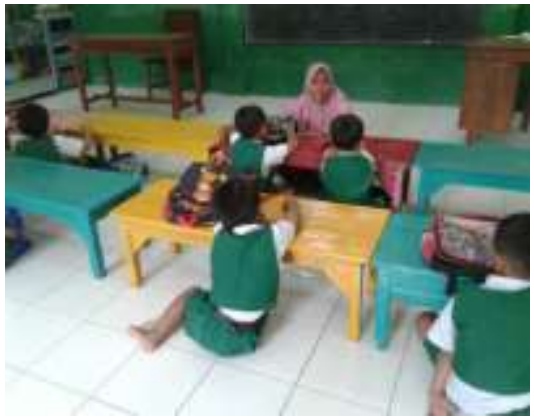

Gambar 2. Model pembelajaran yang ada di RA Miftahul Ulum 
Secara detail, permasalahan yang dialami oleh kedua komunitas dampingan sebagai berikut:

\begin{tabular}{|c|c|c|}
\hline No & Aspek & Permasalahan Komunitas dampingan \\
\hline 01 & SDM Guru & $\begin{array}{l}\text { a. Kurangnya SDM dari guru-guru RA tersebut karena sebagian } \\
\text { besar background pendidikan mereka adalah Sarjana } \\
\text { Pendidikan Islam, bukan khusus Sarjana Pendidikan RA } \\
\text { ataupun TK } \\
\text { b. Kurangnya kreatifitas guru-guru RA dalam membuat media atau } \\
\text { alat peraga edukatif sehingga dalam pembelajaran cenderung } \\
\text { monoton dan membosankan. }\end{array}$ \\
\hline 02 & Pembelajaran & $\begin{array}{l}\text { a. Metode yang digunakan oleh guru masih bersifat klasikal } \\
\text { b. Media pembelajaran yang digunakan oleh kedua komunitas } \\
\text { dampingan hanya berupa majalah berseri sesuai tema. Para guru } \\
\text { tidak memiliki media pembelajaran yang dapat menarik minat } \\
\text { anak-anak untuk semangat dan enjoy dalam belajar. Salah satu } \\
\text { fungsi dari media adalah menarik minat peserta didik. } \\
\text { c. Majalah yang digunakan para guru hanya berisi materi - materi } \\
\text { untuk mengembangkan kecerdasan kognitif saja. Sedangkan } \\
\text { untuk mengembangkan kecerdasan linguistik atau } \\
\text { meningkatkan kemampuan bilingual anak belum ada. Tujuan } \\
\text { dari pembelajaran bilingual adalah untuk meningkatkan kognitif } \\
\text { dan kepribadian anak } \\
\text { d. Media pembelajaran yang digunakan oleh guru masih sangat } \\
\text { sederhana dan mudah rusak. }\end{array}$ \\
\hline 03 & $\begin{array}{l}\text { Sarana dan } \\
\text { Prasarana }\end{array}$ & $\begin{array}{l}\text { a. Sarana dan prasarana kedua komunitas dampingan terbilang } \\
\text { masih kurang memadai dan banyak yang kategori rusak ringan } \\
\text { b. Sebagian besar fasilitas anak baik berupa mainan maupun APE } \\
\text { mengalami kerusakan taraf ringan dan tidak ramah anak. }\end{array}$ \\
\hline 04 & Siswa & $\begin{array}{l}\text { a. Sebagian besar peserta didik merasa jenuh dan bosan dalam } \\
\text { proses pembelajaran. Hal ini disebabkan karena metode guru } \\
\text { dalam mengajar yang masih bersifat konvensional. }\end{array}$ \\
\hline
\end{tabular}

\section{Metode}

Tahapan atau langkah-langkah yang ditempuh guna melaksanakan solusi atas permasalahan spesifik yang dihadapi oleh komunitas dampingan meliputi Edukasi, Training, dan Pendampingan dengan rincian sebagai berikut:

8 Al Amri, M.N, Effects of Bilingualism on Personality, Cognitive and Educational Developments: A Historical Perspective. American Academic \& Scholarly, Research Journal Vol. 5, No. 1, 2013, 1. 
Tabel 4. Metode Pelaksanaan Pengabdian

\begin{tabular}{|c|c|c|}
\hline No & Kegiatan & Langkah-la \\
\hline 01 & $\begin{array}{l}\text { elatihan membuat desain } \\
\text { aku bantal bilingual }\end{array}$ & $\begin{array}{l}\text { - Koordinasi dengan komunitas dampingan terkait } \\
\text { waktu dan tempat } \\
\text { - Membuat materi pendampingan } \\
\text { - Menyiapkan bahan pelatihan } \\
\text { - Metode pelatihan yang digunakan adalah: } \\
\quad \text { lecturing,demonstration, small group discussion, dan praktek }\end{array}$ \\
\hline 02 & $\begin{array}{l}\text { Pendampingan dan pelatihan } \\
\text { dalam praktek membuat } \\
\text { buku bantal bilingual dengan } \\
\text { konten materi-materi } \\
\text { pembelajaran untuk siswa } \\
\text { RA }\end{array}$ & $\begin{array}{l}\text { - Koordinasi dengan komunitas dampingan terkait } \\
\text { waktu, tempat, sarana dan prasarana } \\
\text { - Membuat materi berupa tutorial cara membuat buku } \\
\text { bantal bilingual } \\
\text { - Mempersiapkan semua bahan pendampingan } \\
\text { - Metode yang digunakan dalam pendampingan ini } \\
\text { adalah : ceramah, demonstrasi, small group discussion, } \\
\text { praktek, evaluasi }\end{array}$ \\
\hline 03 & $\begin{array}{lr}\text { Pendampingan } & \text { praktik } \\
\text { mengajar oleh komunitas } \\
\text { dampingan dengan } \\
\text { menggunakan produk buku } \\
\text { bantal bilingual }\end{array}$ & $\begin{array}{l}\text { - Koordinasi dengan komunitas dampingan terkait } \\
\text { waktu } \\
\text { - Metode yang digunakan dalam pendampingan ini } \\
\text { adalah : Pengamatan dan diskusi }\end{array}$ \\
\hline
\end{tabular}

\section{Hasil dan Diskusi}

\section{Pendampingan dan edukasi mengenai materi-materi di RA.}

Kami beserta komunitas dampingan berdiskusi materi apa saja yang dicantumkan pada satu tahun (2 semester). Kemudian kami juga mendampingi komunitas dampingan dalam mentranslate materi-materi tersebut ke dalam bahasa Inggris. Hasilnya, para komunitas dampingan antusias dan semua materi tersusun dengan baik. Adapun tema yang sudah tersusun bersama sebagai berikut : (1) diriku; (2) keluargaku; (3) lingkunganku; (4) tanaman; (5)binatang; (6) kendaraan; (7) alam semesta; dan (8) negaraku.

Pendampingan ini merupakan hal yang penting yang harus dilaksanakan sebelum memulai membuat produk buku bantal. Hal ini supaya media visual buku bantal dimaksud dapat digunakan sesuai dengan kebutuhan RA tersebut. Pentingnya pendampingan ini sesuai dengan hasil penelitian yang dilaksanakan oleh Mazia dan Wisnu. Hasil penelitian tersebut menunjukkan bahwa ada perbedaan penguasaan penyusunan program pembelajaran AUD secara signifikan $(\mathrm{F}=8,576 ; \mathrm{p}<0,01)$ pada kelompok eksperimen setelah mendapatkan perlakuan. Sumbangan efektif pelatihan pada kelompok eksperimen sebesar 61,7\%. Pada kelompok eksperimen, penguasaan penyusunan program pembelajaran AUD mengalami peningkatan $(M D=-6,824$; 


\section{ENGAGEMENT}

Gurnal Pengabdian Kepada Masyarakat

ISSN: 2579-8375 (Print)

ISSN: 2579-8391 (Online)

$\mathrm{p}<0,01)$. Pada kelompok kontrol, setelah diberikan perlakuan, penguasaan subjek juga mengalami peningkatan $(\mathrm{p}<0,00)^{9}$. Dari hasil penelitian ini dapat disimpulkan bahwa penting adanya edukasi atau pendampingan terkait dengan penyusunan perangkat pembelajaran AUD termasuk didalamnya adalah tema.

\section{Edukasi Dan Praktik Tentang Pembuatan Buku Bantal Bilingual.}

Pelatihan tentang teknik menggambar dilakukan dengan memberikan keterampilan menggambar kepada komunitas dampingan, maka kami memberikan edukasi terlebih dahulu mengenai teknik dasar menggambar. Tema-tema yang disepakati bersama adalah transportasi, hewan, dan keluarga. Tahapan ini memberikan manfaat kepada komunitas dampingan dampingan dalam peningkatan skill mereka tentang teknik menggambar. Kemampuan menggambar bagi guru AUD sangat dibutuhkan karena pembelajaran AUD selalu bersinggungan dengan pembelajaran menggambar. Media bergambar juga sangat membantu AUD dalam proses pembelajaran karena implementasi pembelajaran AUD berorientasi pada pembelajaran yang bersifat konkrit. Hal ini sesuai dengan hasil penelitian yang dilaksanakan oleh Endah Hendarwati memgenai media pembelajaran. Hasil penelitian menunjukkan bahwa penting bagi guru untuk menggunakan media pembelajaran dalam proses belajar AUD karena tahapan berfikir anak adalah tahapan berfikir konkrit ${ }^{10}$.

Selain itu, media bergambar ini juga penting bagi anak dalam meningkatkan kemampuan berbicara. Hal ini sesuai dengan hasil penelitian yang dilaksanakan tersebut sesuai dengan penggunaan buku cerita bergambar yang dilakukan oleh PAUD Cinta Ananda dengan melakukan interaksi tanya jawab kepada anak selama bercerita sehingga tingkat kemampuan bahasa anak berada pada posisi tingkat kemampuan ke-3. ${ }^{11}$.

Adapun tahapan dalam pembuatan buku bantal adalah sebagai berikut:

1. Membuat pola gambar di spons ati. Bahan dasar buku bantal ini adalah spons ati. Maka langkah pertama yang harus dilakukan oleh komunitas dampingan adalah membuat atau menggambar pola di spons ati dengan menggunakan pensil. Komunitas dampingan kami bagi

\footnotetext{
${ }^{9}$ Wahyuni, S. (2014). "Pemetaan Kompetensi Pedagogik Guru Taman Kanak Kanak Dalam Mengembangkan Kurikulum Pendidikan Anak Usia Dini Di Kecamatan Margoyoso Kabupaten Pati”, (Doctoral Dissertation, Unne, 2014).

${ }^{10}$ Endah Hendarwati, “ Pemanfaatan Media Dalam Pembelajaran Pengetahuan Sosial Di Taman KanakKanak," Jurnal Pedagogi, Volume 1 Nomor 1, Agustus-2014,1

11 Afnida, M., \& Fitriani, D," Penggunaan Buku Cerita Bergambar Dalam Pengembangan Bahasa Anak Pada Tk a Di Banda Aceh.” Jurnal Ilmiah Mahasiswa Pendidikan Anak Usia Dini, Vol.1, Nomor 1, 2016.
} 


\section{ENGAGEMENT}

Gurnal Pengabdian Kepada Masyarakat

ISSN: 2579-8375 (Print)

ISSN: 2579-8391 (Online)

menjadi beberapa kelompok untuk melaksanakan kegiatan ini supaya lebih efektif dan efisien. Per kelompok sudah disiapkan bahan yaitu spons ati putih yang sudah dipotong-potong seukuran buku, pensil untuk membuat pola, dan spidol untuk menebalkan pola. Hasil dari tahapan ini adalah komunitas dampingan dampingan secara maksimal membuat pola tersebut dengan didampingi oleh Tim Pengabdian di kelompok masing-masing. Bahan dasar yang digunakan pada pembuatan buku bantal ini adalah spons ati berwarna putih. Pemilihan spons ati ini bukan tanpa sebab dan alasan. Kami memilih spons ati karena sesuai dengan tema yaitu buku bantal, maka tekstur spons ati ini empuk dan lembut. Selain itu bahan ini juga mudah untuk dibersihkan, nyaman dan ramah anak. Ini sesuai dengan prinsip pengabdian kami bahwa membuat media bagi AUD yang ramah anak. Ini juga sesuai dengan hasil penelitian yang dilakukan oleh Marlin D. Susanti yang menunjukkan hasil bahwa media pembelajaran yang ramah anak seperti flanel dan barang bekas dapat meningkatkan motivasi anak dalam belajar. ${ }^{12}$

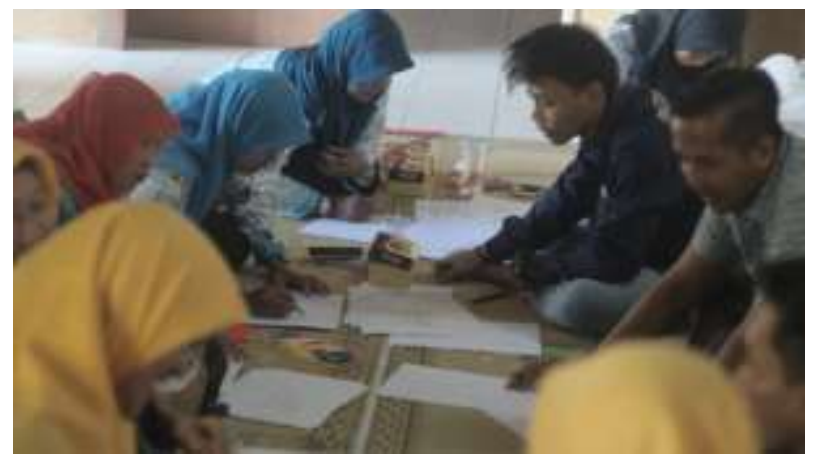

Gambar 3. Membuat pola gambar

2. Pewarnaan gambar dengan metode melukis. Setelah komunitas dampingan menggambar di spons ati, komunitas dampingan kemudian melukis gambar tersebut dengan cat sesuai dengan kebutuhan gambar. Hal ini dilakukan supaya gambar tersebut semakin cantik dan hidup. Pengecatan ini menggunakan Cat Mowilex sehingga tahan lama dan tidak luntur. Warna yang dipilih adalah warna-warna cerah yang sesuai dengan gaya anak. Selain itu, warna-warna juga disesuaikan dengan kondisi riil lingkungan. Seperti pohon berwarna hijau, tanah berwarna coklat, dan awan berwarna biru muda. Pewarnaan pada produk akan

12 Susanti," Pemanfaatan Media Pembelajaran Terhadap Motivasi Belajar Anak Tk." Jurnal Pendidikan Anak, Vol.4, Nomor 2, 646

Volume 2, Number 1, Mei 2018| 128 Pemberdayaan Guru RA Melalui Edukasi Media Visual “Buku Bantal Bilingual” di Sukosono Kedung Jepara Jawa Tengah 


\section{ENGAGEMENT}

Gurnal Pengabdian Kepada Masyarakat

ISSN: 2579-8375 (Print)

ISSN: 2579-8391 (Online)

menciptakan keingintahuan siswa/anak didik terhadap produk tersebut sehingga tertarik untuk belajar.

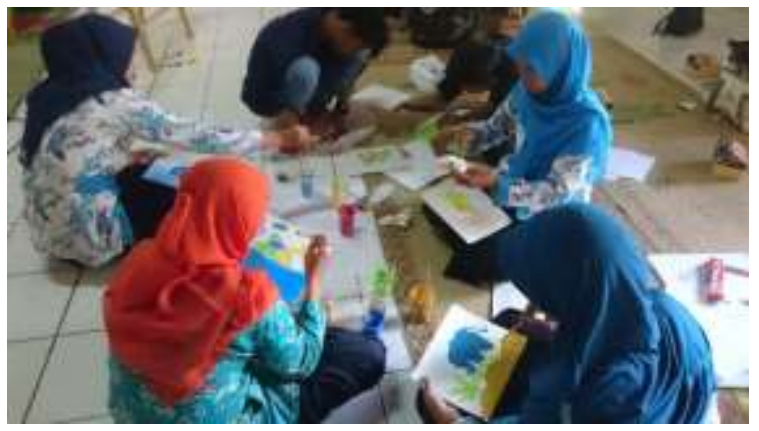

Gambar 4. Tahapan Mengecat Gambar

3. Supaya gambar terasa nyata dan hidup. Komunitas dampingan juga menambahkan pernakpernik berupa mata di gambar-gambar tersebut. Pernak-pernik tersebut ditempelkan dengan menggunakan lem tembak yang sudah tersedia. Gambar yang diberi pernak pernik adalah gambar binatang, dan keluarga. Ini memberikan kesan pada gambar lebih hidup dan menarik.

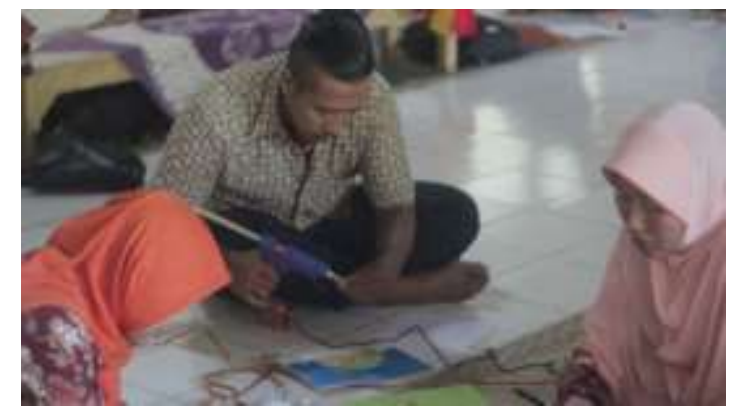

Gambar 5. Penempelan Pernak -pernik

4. Penulisan Bilingual. Supaya gambar tersebut memiliki nilai literasi dan meningkatkan kecerdasan linguistik anak. Maka komunitas dampingan membuat tulisan bilingual (bahasa Indonesia dan bahasa Inggris) untuk gambar-gambar yang sudah dibuat. Sehingga informasi yang ingin disampaikan ke peserta didik bisa komprehensif. Penulisan tersebut menggunakan spidol marker dan ditulis di kain flanel. Kemudian flanel tersebut digunting sesuai ukuran tulisan untuk ditempelkan di lembar spons ati menggunakan lem tembak.

Tahapan ini merupakan salah satu bagian penting yang dalam pembuatan produk karena penulisan kata bilingual ini memberikan manfaat bagi peningkatan kecerdasan linguistik anak. Ini sesuai dengan hasil penelitian yang dilakukan oleh Ria Astuti dengan hasil bahwa setiap anak mampu mengembangkan bahasa selain secara alami juga dipengaruhi oleh dunia 


\section{ENGAGEMENT}

Gurnal Pengabdian Kepada Masyarakat

ISSN: 2579-8375 (Print)

ISSN: 2579-8391 (Online)

pendidikan. Selain itu, pembelajaran bilingual pada anak usia dini tidak boleh dengan paksaan dan harus dilakukan dengan kegiatan yang menyenangkan ${ }^{13}$. Dari hasil penelitian tersebut menunjukkan bahwa pembelajaran bilingual harus dilakukan dengan kondisi fun dan nyaman sehingga proses pembelajaran dapat berjalan secara maksimal. Hal ini sesuai dengan pengabdian ini bahwa konsep bilingual ini dibuat dengan menarik dan inovatif sehingga meningkatkan antusiasme anak dalam belajar.

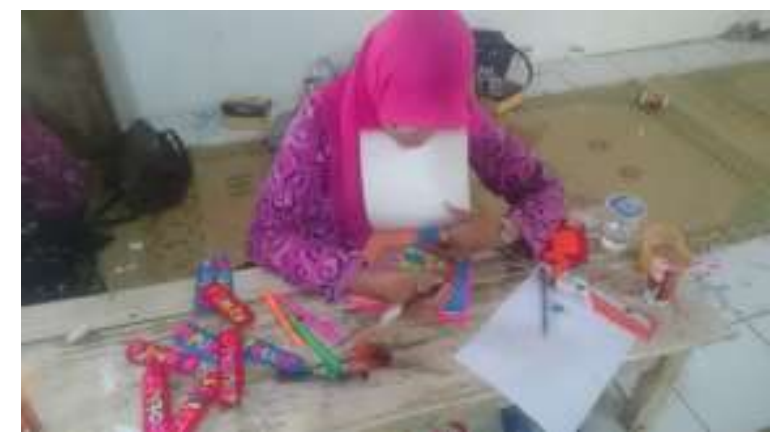

Gambar 6. Penulisan Bilingual

5. Penyatuan gambar-gambar menjadi buku dengan teknik menjahit. Setiap tema yang telah disepakati oleh komunitas dampingan, terdapat 5 lembar gambar yang kemudian dijadikan satu menjadi buku. Penyatuan lembar-lembar gambar tersebut dengan cara dijahit supaya lebih rekat dan kencang. Hasil dari tahapan ini adalah para komunitas dampingan dampingan dengan semangat dan detil menjahit semua lembar buku yang telah disusun. Dengan teknik menjahit ini, maka buku bantal ini lebih tahan lama dan tidak mudah sobek. Sesuai yang disampaikan oleh Badru Zaman dan Cucu yang menyatakan bahwa salah satu prinsip pemilihan media pembelajaran yaitu persyaratan fisik, kuat dan tahan lama ${ }^{14}$.

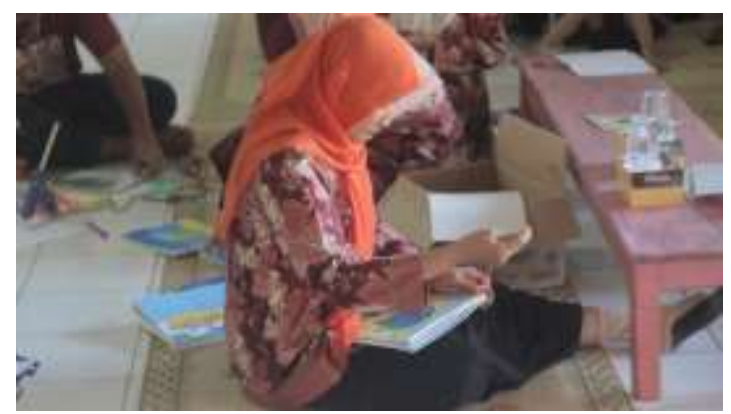

Gambar 7. Teknik menjahit untuk Menyatukan lembaran gambar

13 Astuti, R," Penerapan Pembelajaran Bilingual Di TK Inklusi," Jurnal Pendidikan Anak, Vol.3 Nomor 2, 2017, 109.

14 PPG, P. P. G. Media pembelajaran anak usia dini, 2010.

Volume 2, Number 1, Mei 2018| 130

Pemberdayaan Guru RA Melalui Edukasi Media Visual “Buku Bantal Bilingual” di Sukosono Kedung Jepara Jawa Tengah

Santi Andriyani, Yushinta Eka Farida, DS. Drajat Wibowo 


\section{ENGAGEMENT}

Gurnal Pengabdian Kepada Masyarakat

ISSN: 2579-8375 (Print)

ISSN: 2579-8391 (Online)

6. Pembuatan cover buku. Tahapan yang terakhir adalah pembuatan cover tiap buku. Bahan yang digunakan adalah spons ati yang dilapisi dengan kain flanel. Penempelan cover tersebut tidak dengan teknik menjahit tetapi dengan lem tembak. Hasilnya, jumlah kelompok sebanyak 4 dan tiap kelompok membuat 2 buku yang temanya berbeda-beda. Adapun tulisan cover juga dibuat semenarik mungkin yang terbuat dari kain flanel yang didalamnya diberi bahan dacron supaya huruf pada cover buku tersebut terasa nyata kemudian dijahit. Hal ini membuat cover buku menjadi menarik.

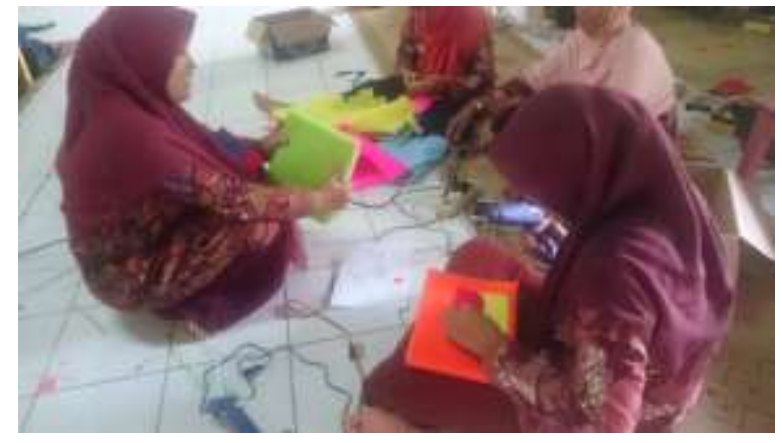

Gambar 8. Pembuatan Cover Buku

7. Pelatihan dan pendampingan mengenai media visual buku bantal bilingual, kami menyebarkan angket kepada seluruh peserta sebanyak 18 responden mengenai evaluasi program pendampingan. Hal ini bertujuan untuk melihat sejauhmana respon komunitas dampingan dan kebermanfaatan program ini bagi komunitas dampingan dampingan. Adapun hasilnya adalah :

Pertama, dari aspek materi. 16 responden atau sebanyak 90\% menyatakan baik sedangkan 2 responden atau $10 \%$ menyatakan cukup. Aspek materi terdiri dari beberapa item yaitu : a) kecukupan materi tentang media pembelajaran. Pada aspek ini kami mengadakan sosialisasi mengenai pentingnya media pembelajaran yang menarik dan fun bagi AUD; b) materi sesuai dengan yang dibutuhkan komunitas dampingan. Dalam hal ini kami juga melakukan pendampingan terhadap komunitas dampingan mengenai pemetaan materimateri RA dan menyusun tema sesuai dengan kurikulum yang berlaku.; c) kebermanfaatan materi untuk guru dan siswa. Hasil dari angket menyatakan 90\% baik maka dapat dideskripsikan bahwa materi ini memang berguna bagi guru dan siswa; dan d) keefektifan penggunaan media dalam pembelajaran. Ini juga bisa dilihat dari praktik komunitas dampingan saat penggunaan media dalam proses belajar mengajar. Aspek materi ini menjadi hal yang penting dalam proses pembuatan media visual buku bantal bilingual, karena materi 
ini menjadi konten dalam produk yang akan di transformasikan kepada peserta didik. Pentingnya materi ini sesuai dengan hasil artikel pengabdian yang dilaporkan oleh Nurul Zuriyah dkk yang menunjukkan hasil bahwa pengembangan bahan ajar yang kreatif dan inovatif dimulai salah satunya dengan pemetaan materi yang sesuai ${ }^{15}$.

Kedua, dari aspek pelatihan dan pendampingan menunjukkan bahwa $100 \%$ tergolong baik. Adapun item pada aspek ini adalah: (a) kejelasan dalam tahapan praktik. Untuk memudahkan komunitas dampingan dalam praktik, kami membuat Power Point tutorial tahapan cara membuat buku bantal bilingual yang kami tayangkan pada saat pelatihan; (b) kelengkapan alat dalam pelaksanaan praktik. Supaya komunitas dampingan dampingan terfasilitasi dengan baik saat pelatihan, kami menyiapkan bahan-bahan pelatihan sebanyak 4 kelompok. Bahan-bahan tersebut tersebut meliputi, spons ati, flanel, pensil, penggaris, gunting, lem tembak beserta alatnya, cat, pernik-pernik dan alat jahit; (c) pendampingan dalam tahapan menggambar. Supaya pendampingan ini efektif, kami juga mengajak mahasiswa desain produk untuk mendampingi komunitas dampingan dampingan dalam membuat gambar; (d) pendampingan dalam tahapan pengecatan. Pendampingan ini dimulai dengan pengenalan warna primer dan bagaimana pencampuran warna; dan (e) pendampingan dalam tahapan finishing buku. Evaluasi pada item ini menjadi penting supaya kami tahu sejauhmana kontribusi tutor/fasilitator dalam tahap akhir pembuatan buku bantal tersebut. Pentingnya aspek pelatihan dan pendampingan ini sesuai dengan hasil penelitian yang dilaksanakan oleh Hanik dan Asma yang menunjukkan hasil bahwa kapasitas guru MINU Waru Sidoarjo dalam mengembangkan media pembelajaran berbasis Teknologi Informasi meningkat melalui penerapan pelatihan pengembangan media pembelajaran interaktif berbasis MsPower Point ${ }^{16}$. Dari hasil penelitian tersebut dapat disimpulkan bahwa penting adanya pendampingan dan pelatihan dalam pengembangan/pembuatan media pembelajaran.

Ketiga, dari aspek tutor/fasilitator juga menunjukkan hasil sebanyak 18 responden atau sebanyak $100 \%$ menyatakan hasil baik. Adapun item pada aspek tutor adalah : (a) kesesuaian program dengan keahlian para tutor. Sesuai dengan tema pada program pengabdian ini yaitu buku bantal bilingual, maka keahlian yang dimiliki oleh tutor adalah

15 Zuriah, N., Sunaryo, H., \& Yusuf, N, "Ibm guru dalam pengembangan bahan ajar kreatif inovatif berbasis potensi local”. Jurnal Dedikasi, Volume 13, 2016, 39

16 Alfiyah, Fauziyah, \& Masfufah, M. "Pengembangan Kapasitas Guru Melalui Pengembangan Media Pembelajaran Interaktif Berbasis Teknologi Informasi Di Minu Waru Sidoarjo.” UIN Sunan Ampel Journal of Islamic Education, Volume 4, Nomor 1, 2016, 157.

Volume 2, Number 1, Mei 2018| 132 Pemberdayaan Guru RA Melalui Edukasi Media Visual “Buku Bantal Bilingual” di Sukosono Kedung Jepara Jawa Tengah 


\section{ENGAGEMENT}

Gurnal Pengabdian Kepada Masyarakat

ISSN: 2579-8375 (Print)

ISSN: 2579-8391 (Online)

keilmuan bidang desain dan bidang bahasa (bahasa Indonesia dan bahasa Inggris); dan (b) komunikasi aktif tutor. Selama pelatihan kami selalu memberikan brain-game di awal pelatihan sehingga pelatihan berjalan dengan nyaman dan interaktif.

Berdasarkan deskrispsi di atas disimpulkan bahwa hasil angket evaluasi program menunjukkan program pendampingan ini menjadi kebutuhan yang penting bagi komunitas dampingan dampingan untuk meningkatkan kreatifiats dan inovasi komunitas dampingan dalam proses pembelajaran di RA.

\section{Observasi Pendampingan Kebermanfaatan Produk Buku Bantal Bilingual}

Untuk melihat kebermanfaatan produk buku bantal bilingual, kami juga melakukan observasi dan pendampingan saat guru RA praktik di kelas dengan menggunakan media visual buku bantal bilingual tersebut. Hasil dari observasi kami, menunjukkan bahwa : (1) Media tersebut mulai dikenalkan kepada anak saat tahapan pendahuluan dalam pembelajaran; (2) Produk yang digunakan pada saat praktik adalah bertemakan keluarga/my family; (3) Produk tersebut digunakan dalam menyampaikan materi pembelajaran "My Family", (4) Komunitas dampingan juga melibatkan anak RA dalam penggunaan produk yaitu dengan melakukan games " matching words"; (5) saat tahapan penutup, komunitas dampingan juga melaksanakan review bersama dengan anak RA dengan melakukan recalling mengenai nama-nama keluarga secara bilingual (bahasa Indonesia dan Bahasa Inggris).

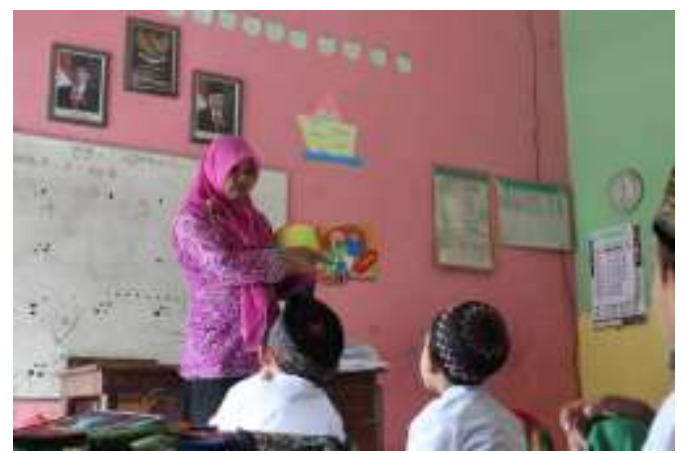

Gambar 9. Praktik mengajar menggunakan Produk

Dari deskripsi di atas, dapat disimpulkan bahwa media visual buku bantal tersebut digunakan untuk meningkatkan perkembangan dan pertumbuhan kognitif, motorik halus, sosial emosional, dan juga bahasa. Ini sesuai dengan hasil penelitian yang dilakukan oleh Asmariani yang menyatakan bahwa media pembelajaran dapat meningkatkan perkembangan sosial 


\section{ENGAGEMENT}

Gurnal Pengabdian Kepada Masyarakat

ISSN: 2579-8375 (Print)

ISSN: 2579-8391 (Online)

emosional anak dan juga kognitif anak. ${ }^{17}$ Perkembangan tersebut dapat dilihat dari aktifitas yang dilakukan oleh guru dan murid yaitu kegiatan kuis/games. Selain itu kegiatan tebak gambar dan juga tanya jawab yang dilakukan antara guru dan murid juga dapat meningkatkan pemahaman anak mengenai materi yang disampaikan.

Setelah praktik mengajar berakhir, kami juga membagikan angket kepada responden/komunitas dampingan dampingan untuk melihat keefektifan produk media visual “ buku bantal bilingual". Angket tersebut berisi tentang kualitas produk dan kebermanfaatan produk dalam pembelajaran baik bagi komunitas dampingan maupun anak didik (RA). Adapun hasilnya adalah :

Pertama, dalam aspek kualitas produk, sebanyak 18 responden menyatakan bahwa kualitas produk buku bantal bilingual yang telah dibuat adalah baik dengan skor 4. Adapun aspek ini meliputi: (a) keamanan dan kenyamanan produk bagi anak; (b) kreatifitas gambar pada produk; (c) perpaduan warna pada produk; dan (d) kejelasan bahasa bilingual yang tertuang pada produk. Inti pada aspek ini adalah ingin mengevaluasi dan mengetahui sejauhmana kualitas produk yang dibuat oleh komunitas dampingan dengan berbagai pendampingan yang telah dilakukan oleh tim. Tampilan produk ini menjadi hal penting seperti yang dikemukakan oleh Levie dan Lentz dalam Azhar Arzyad mengemukakan bahwa salah satu fungsi dari pemanfaatan media adalah fungsi atensi. Media visual dipergunakan sebagai alat sentral dalam proses pembelajaran. Tampilan atau bentuk media visual yang menarik akan mengarahkan peserta didik untuk berkonsentrasi pada materi yang disampaikan ${ }^{18}$.

Kedua, dalam aspek kebermanfaatan produk, sebanyak 18 responden bahkan menyatakan bahwa kebermanfaatan produk bagi komunitas dampingan dan anak didik menyatakan sangat baik dengan skor 5. Adapun item pada aspek ini meliputi: (a) kemudahan penggunaan produk dalam proses pembelajaran; (b) kebutuhan produk yang sesuai dengan kurikulum; (c) inovasi produk untuk media pembelajaran; (d) peningkatan minat belajar anak melalui produk; (e) peningkatan kecerdasan linguistik anak melalui produk; dan ( $\mathrm{f}$ ) peningkatan kreatifitas guru melalui produk. Aspek ini bertujuan untuk melihat sejauhmana produk ini dapat diimplementasikan dalam proses belajar mengajar dan sejauhmana efektifitas penggunaan produk dalam proses belajar mengajar. Inti dari aspek ini adalah sejauhmana media visual ini dapat

17 Asmariani, A. "Konsep Media Pembelajaran Paud," Al-Afkar: Jurnal Keislaman \& Peradaban, Volume 5, Nomor 1, 2016, 25.

18 Azhar, Arsyad, Media Pembelajaran. (Jakarta: Raja Grafindo Persada, 2005), 16. 


\section{ENGAGEMENT}

Gurnal Pengabdian Kepada Masyarakat

ISSN: 2579-8375 (Print)

ISSN: 2579-8391 (Online)

meningkatkan minat belajar anak. Hal ini selaras dengan hasil penelitian yang dilakukan oleh Zaini dkk yang menyatakan bahwa media film pendek dapat meningkatkan minat dan hasil belajar pada mata pelajaran sosiologi siswa kelas X IPS 1 SMA Negeri 5 Surakarta pada tahun pelajaran 2016/2017 ${ }^{19}$. Selain itu, Oemar Hamalik juga menyatakan bahwa media media dapat membangkitkan motivasi dan pengaruh psikologis bagi peserta didik $^{20}$.

Berdasarkan hasil program pendampingan menunjukkan bahwa produk buku bantal ini memiliki kualitas yang baik dilihat dari bahan yang ramah bagi anak, perpaduan warna dan gambar yang sesuai, dan juga inovasi bilingual yang ditampilkan. Adapun pada aspek kebermanfaatan, dilihat dari minat anak didik yang tinggi dan juga peningkatan kreatifiats guru dalam mengelola kelas dengan menggunakan produk tersebut.

\section{Simpulan}

Simpulan dari program ini menunjukkan bahwa: luaran atau produk dalam kegiatan ini berupa buku bantal dengan bahan dasar spons ati berdasarkan tema RA dengan tulisan bilingual (Bahasa Indonesia dan Bahasa Inggris). Hasil dari pendampingan pembuatan produk juga menunjukkan bahwa komunitas dampingan dapat mempraktekkan pembuatan buku bantal sesuai dengan tahapan-tahapannya, mulai menggambar, mengecat, memberi tulisan, menempel, memberi hiasan dan menjahit. Hasil proses pendampingan menunjukkan bahwa komunitas dampingan mampu meningkatkan kreatifitas dan inovatif dalam pengembangan media pembelajaran bagi anak usia dini (AUD). Selain itu, dengan menggunakan media buku bantal, komunitas dampingan mampu mengimplementasikan buku bantal sebagai media pembelajaran di kelas sehingga menjadikan pembelajaran dikelas fun dan menarik.

\section{Daftar Referensi}

Afnida, \& Fitriani, " Penggunaan Buku Cerita Bergambar Dalam Pengembangan Bahasa Anak Pada Tk a Di Banda Aceh.” Jurnal Ilmiah Mahasiswa Pendidikan Anak Usia Dini, Vol.1, Nomor 1, 2016.

$\mathrm{Al}$ Amri, "Effects of Bilingualism on Personality, Cognitive and Educational Developments: A Historical Perspective. American Academic \& Scholarly”, Research Journal Vol. 5, No. 1, 2013.

${ }^{19}$ Erivianto, D. "Penerapan Media Film Pendek Untuk Meningkatkan Minat Belajar Dan Hasil Belajar Siswa Pada Mata Pelajaran Sosiologi Kelas X IPS 1 SMA Negeri 5 Surakarta Tahun Pelajaran 2016/2017," SOSLALITAS; Jurnal Ilmiah Pend. Sos Ant, Volume 7, Nomor 2, 2017.

20 Oemar, Hamalik, Media Pendidikan. ( Bandung: Citra Aditya Bakti, 1994), 18.

Volume 2, Number 1, Mei 2018| 135 Pemberdayaan Guru RA Melalui Edukasi Media Visual “Buku Bantal Bilingual” di Sukosono Kedung Jepara Jawa Tengah 
Arsyad Azhar. Media Pembelajaran. Jakarta: Raja Grafindo Persada, 2014.

Arsyad,Azhar Media Pembelajaran. Jakarta: Raja Grafindo Persada, 2005.

Asmariani, A. "Konsep Media Pembelajaran Paud," Al-Afkar: Jurnal Keislaman \& Peradaban, Volume 5, Nomor 1, 2016.

Astuti, R. ," Penerapan Pembelajaran Bilingual Di TK Inklusi," Jurnal Pendidikan Anak, Vol.3 Nomor 2, 2017.

Barnawi \& Ardy Wiyani, Novan. Format PAUD . Jakarta: Ar-Ruzzmedia, 2011.

Erivianto, D. "Penerapan Media Film Pendek Untuk Meningkatkan Minat Belajar Dan Hasil Belajar Siswa Pada Mata Pelajaran Sosiologi Kelas X IPS 1 SMA Negeri 5 Surakarta Tahun Pelajaran 2016/2017," SOSIALITAS; Jurnal Ilmiah Pend. Sos Ant, Volume 7, Nomor 2, 2017.

Fauziyah,Alfiyah \& Masfufah, "Pengembangan Kapasitas Guru Melalui Pengembangan Media Pembelajaran Interaktif Berbasis Teknologi Informasi Di Minu Waru Sidoarjo." UIN Sunan Ampel Journal of Islamic Education, Volume 4, Nomor 1, 2016.

Hamalik. Keterampilan Dasar Mengajar. Malang: Fakultas Tarbiyah Press, 2005.

Hendarwati, Endah, “Pemanfaatan Media Dalam Pembelajaran Pengetahuan Sosial Di Taman Kanak-Kanak,” Jurnal Pedagogi, Volume 1 Nomor 1, Agustus-2014.

Khadijah. Media Pembelajaran AUD. Medan: Perdana Publishin, 2015.

Oemar, Hamalik, Media Pendidikan. Bandung: Citra Aditya Bakti, 1994.

PPG, P. P. G. (2010). Media Pembelajaran Anak Usia Dini.

Sujiono, Yuliani Nurani. Konsep Dasar Pendidikan Anak Usia Dini. Jakarta: PT. Indeks, 2012.

Susanti," Pemanfaatan Media Pembelajaran Terhadap Motivasi Belajar Anak Tk." Jurnal Pendidikan Anak, Vol.4, Nomor 2.

Suyadi. Psikologi Belajar Anak Usia Dini. Yogyakarta : PEDAGOGIA, 2010.

Wahyuni, "Pemetaan Kompetensi Pedagogik Guru Taman Kanak Kanak Dalam Mengembangkan Kurikulum Pendidikan Anak Usia Dini Di Kecamatan Margoyoso Kabupaten Pati”, (Doctoral Dissertation, Unnes, 2014)

Zuriah, dkk, "Ibm guru dalam pengembangan bahan ajar kreatif inovatif berbasis potensi local". Jurnal Dedikasi, Volume 13, 2016.

Volume 2, Number 1, Mei 2018| 136

Pemberdayaan Guru RA Melalui Edukasi Media Visual “Buku Bantal Bilingual” di Sukosono Kedung Jepara Jawa Tengah 